\title{
CAREFUL, YOU MIGHT LOSE SOMETHING: ON BEING DISCIPLINED INTO THE ANTHROPOLOGY OF RELIGION
}

By Ingie Hovland (Department of Anthropology, School of Oriental and African Studies, University of London)

\section{ABSTRACT:}

This paper reflects on the experience of entering into the academic field of the anthropology of religion. Its reflections are prompted by a perceived division in the anthropology of religion between the Other (whose religion is the target of incessant and persistent questions) and the Self (whose religion is a fairly sensitive issue that is decidedly not questioned). The paper explores by what means the two sides of such a double phenomenon are able to coexist, and asks what repressions and exclusions are necessary in order to sustain the deceptively simple anthropological procedure where the Self examines/explains (the religion of) the Other?

The episteme is not a general stage of reason, it is a complex relationship of successive displacements. (Foucault 1978b:10)

\section{MONDAY}

On my way home. The bus is stuck in traffic by the roadworks at Shoreditch again. Am thinking about my conversation with Prof $\mathrm{N}$ today. He asked me about my research proposal, and when I told him it was about Christian missionaries and the way they have changed over the past 150 years he had lots of questions - about what they have done, what motivated them in the past, what motivates them now, what they believe, etc., etc. The kind of questions that I will be asking continuously for the next couple of years. But what I am really struck by right now is what he did not ask; in particular: why didn't he ask me about God? About what I believe? Then again, if he had actually asked me I would have been so surprised that I don't know what I would have answered. That question somehow seems out of place in an academic corridor.

Aim for the week: Explore further these two sides of being a student of the anthropology of religion: On the one hand, there is the incessant and persistent questioning of the religion of the (researched) Other. On the other hand, there is a deliberate and equally persistent lack of questioning of the religion of the (researcher) Self. In true structuralist fashion:

$\begin{array}{ccl}\text { Beliefs and practices of Self } & : & \text { Beliefs and practices of Other } \\ \text { No questioning (a bit sensitive) } & : & \begin{array}{l}\text { Incessant questioning } \\ \text { intriguing) }\end{array} \quad \text { (a bit }\end{array}$

There is something that feels uncomfortable about being part of an establishment characterised by this kind of divide, but I can't quite place my finger on it at the moment.

The scenario reminds me of Foucault's description of a double phenomenon in the history of sexuality in Western societies: the misunderstanding and silence about sexuality at the level of the individual has been coupled with an intensive and excessive 'over-knowledge' about sexuality at a theoretical and societal level. Insistent prohibition has been combined with obsessive production. (Remember to look up the chapter when I get home - what was his point?) 
Must also remember to look for a church that I can go to, on Sunday, so that I can write that mini-ethnography about a church service.

Finally home. Foucault's point seems to have been that although the double phenomenon appears as a contradiction (individual prohibition on the one hand, societal over-production on the other), the two sides of the process are actually not contradictory at all. Instead, they coexist and may even effectively depend on and enhance each other. Moreover, if we examine double phenomena at society's margins (such as sexuality), they will tell us something about the phenomena that are placed at society's centre (such as ourselves). Found a malleable quote:

.... at base the West is not really denying sexuality (it does not exclude it); but the West introduces to sexuality, it develops, starting with sexuality, an entire complex mechanism in which it is a question of the constitution of individuality, of subjectivity (Foucault 1999:129).

In other words, at base anthropology is not really denying religion (it does not exclude it); but anthropology introduces to religion, it develops, starting with religion, an entire complex mechanism in which it is a question of the constitution of individuality, of subjectivity...explicitly of the Other. And, implicitly, of the Self.

\section{TUESDAY}

In the library. I am studiously (and quite successfully) ignoring the list of ethnographies that my supervisor has suggested I should read. They are all preoccupied with questioning the religion of the Other. What I want to find out about is the absence of questioning of the religion of the Self. Why do we try to understand the religion of the Other? Is it a roundabout way of trying to understand (the religion of) the Self? Or are we trying to push away an understanding of the Self - to displace or project this non-understanding of the Self onto the Other?

l've paged through a couple of readers on the anthropology of religion, but didn't have much luck in finding material on these questions. I have now relocated to the psychoanalysis section, on the hunch that absence and silence may have something in common with displacement and repression.

At the moment I am struggling through random paragraphs in Lacan's Écrits. I at least pick up on his point that the Self is constituted by the Other, more specifically by images that the Other reflects back to the Self (Lacan's example is the dynamic between the baby and its mother). Another point that seems relevant is his comment that the unconscious is the discourse of the Other. We seem to be talking about two 'Others' to the Self: both the Other as external other person(s), and the Other as the internal unconscious. Both these Others constitute the Self. Remembering Foucault's interest in the margins of society as a means of understanding the Self, I think Lacan has something to add here in terms of using the margins of the Self as a means of understanding this Self.

I also think he has something to add regarding the assumed process of anthropological fieldwork where 'the Self examines/explains the Other'. This deceptively simple presentation of what anthropologists do relies on the assumption that the anthropologist Self is self-conscious. An assumption that might be challenged by a crude application of Lacan's concept of divisions 
within the Self - between what appears to us as rational/self-conscious processes and, on the other hand, Other/unconscious processes. Apply Lacan's tongue-in-cheek critique of the Cartesian 'I think therefore I am' to the anthropologist researcher:

I think where I am not, therefore I am where I do not think...What one ought to say is: I am not wherever I am the plaything of my thought; I think of what I am where I do not think to think. (Lacan 1977:166, my emphasis)

If Lacan's 'I think' refers to the imagined self-conscious Cartesian cogito, then 'I am' refers to the unconscious - or the Other of the Self. In my binary framework:

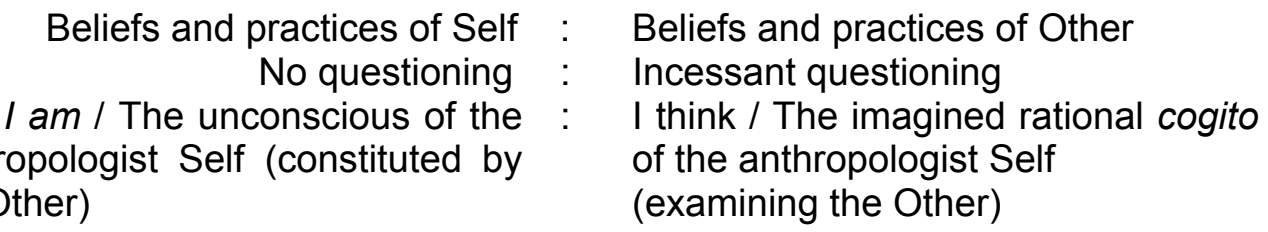

\section{WEDNESDAY}

Have had a foretaste of what it will be like to negotiate a bearable researcher identity today through two encounters, one with academia and one with the mission society.

Encounter one. Met Prof $\mathrm{F}$ in the corridor and he asked me how things were going. I told him that I am planning to attend a church service on Sunday to write a mini-ethnography, at which point he suggested a few churches I might go to that he had heard of, but then jokingly warned: 'Careful, you might lose something!' It's interesting that he takes for granted that I don't usually go to church and that I therefore need suggestions about possible churches. I am also quite intrigued by what exactly it is he thinks I might lose (- my anthropological soul, perhaps? Or my credentials as a reasonably sane person?). The supposition seems to be that as a student of the anthropology of religion it is taken for granted that I don't have religious beliefs. Or, if by some mysterious circumstance I should turn out to have religious beliefs anyway, then obviously I will keep this to myself and not muddle it up with my studies of religion. Even more interesting is the fact that I felt so consigned to this role there in the academic corridor that I merely nodded to what he was saying in as atheistic a manner as I could manage.

Encounter two. Later I phoned up the mission society to confirm that I would be allowed access to their archives. I got a Mrs $\mathrm{J}$ on the phone. (Have I spoken to her before?) She recognised my name and told me she had prayed for me when I was little and my parents were stationed as missionaries in South Africa. I thanked her - and suddenly found myself, rather awkwardly, trying to use a Christian discourse again to be able to communicate my gratitude. She took it for granted that I must be a Christian; at least that I must be happy to have been prayed for - my parents were missionaries, after all.

It is beginning to dawn on me that any divisions in the anthropology of religion cannot simply be kept at the abstract level of the nature of knowledge within the field. The divisions supplant themselves downwards to the researcher and present themselves as practical negotiations over identity (the id-word yet again), leading on to immediate methodological problems. As Deleuze \& Guattari would argue, macro ruptures and repressions at the level of the nature of knowledge in the field manifest themselves in, and are sustained by, micro ruptures: repressions, anxieties and frustrations at the level of the individual researcher. According to them, micro ruptures do not just appear out of nowhere; they can be traced back to macro ruptures. The trick would be 
to see the link between the macro and the micro ruptures and processes. But once I've seen a link - what do I do after that?

Previously I have always read Deleuze \& Guattari to apply their theory to others' situation; now that it suddenly seems to apply in some way to my own, it gives me that same uncomfortable feeling. Must talk to $\mathrm{K}$ tomorrow to see whether she has had the same problems in her work as an anthropologist.

\section{THURSDAY}

Phoned K. She has had some of the same difficulties concerning the negotiation of her identity, but she has solved the dilemma by keeping her beliefs strictly separate from her research. When she conducts anthropological fieldwork and research she brackets out her own presuppositions and opinions, and tries to meet and understand the people she is studying on the basis of their own values:

$$
\begin{aligned}
\text { Private } & : \text { Academic } \\
\text { Beliefs and practices of Self } & : \text { Beliefs and practices of Other } \\
\text { No questioning/private questioning } & : \begin{array}{l}
\text { Incessant questioning by the } \\
\text { academic }
\end{array}
\end{aligned}
$$

In a way, it seems like she has dealt with the private/academic divide in the academic field by internalising it and making it her own personal divide. I am not sure whether that would solve anything for me. I am also wondering whether it would not be more of an illusion for the benefit of the academic establishment than a genuinely effective research tool.

After the conversation with $\mathrm{K}$, I presented my impasse to $\mathrm{P}$ and $\mathrm{L}$ in the kitchen. They adopted their usual non-reverential attitude towards the religion of anthropology. Abbreviated transcript:

P: I didn't quite get that - what's your problem? Are you struggling with how to be objective as an anthropologist of religion?

Me: No, no, no. Of course I can't be objective. Anthropology has been hit by the reflexive turn too.

P: Ok, great. Then you can be subjective as an anthropologist of religion.

Me: Well, yes - obviously I have to be subjective about my presence when doing research, how I potentially influence the setting, how I interpret events and so on. But I can't really drag in any beliefs. They're taboo in the anthropology of religion.

P: Right... So you're going to effectively ignore any beliefs you might have, because as a researcher they're taboo and the rest of academia don't want to know, and then you're going to go away and do research on somebody else's taboos and religious beliefs, which as a researcher you will be able to examine and maybe explain - to the rest of academia. And you have to go through this whole displaced process because that will ensure top quality research and only then will the rest of academia want to know about taboos and religious beliefs. Is that it?

Me: Er... It's not all that displaced, really ...

L: Why do people do anthropology again? 
Me: Remind me.

$\mathrm{L}$ : I thought one of the reasons was that an understanding of how other people organise and think about their lives would give us a better understanding of our own lives.

Me: Good point, yes. Something like that.

L: But the way you're talking about it, it sounds like you're not going to use any understanding of your own position to understand others' position, since any beliefs of your own won't enter into the equation. And then when you've understood the others' position, it's not going to be used to better understand your own position, because, again, that would be outside the limits of the academic research. Do you see what I mean? It's as if your reason for doing anthropological research in the first place - the whole movement between yourself and the others and then back to yourself again - is just cut off in this academic field. So...

$\mathrm{P}: \quad$ So what exactly is the point of the anthropology of religion?

At that point the seeming meaninglessness of it started to get to me, and we changed the topic to a discussion of the strange behaviour of our hamster instead.

\section{FRIDAY}

On the bus. Stuck. At Shoreditch. Again. I am reviewing the week's various binarisms: Self/Other, no questioning/incessant questioning, unconscious/rational, private/academic. In a way they are much too tidy. Perhaps that's why they verge on the meaningless.

Am trying to remember what Derrida said in Of Grammatology about binary oppositions. He would probably ask something along the lines of: By what means has such a system of binary oppositions been made to make sense? What repressions and exclusions does it rely on? And in order to explore these repressions and exclusions, he might ask: Which concepts would be undecidable within the system - i.e. which concepts cannot decidedly be placed on either one side or the other of the binary oppositions - and thus threaten to destabilise the system? I remember the best example I have ever been given of an undecidable was a zombie. A zombie is both alive and dead, neither alive nor dead; zombies freak us out. So - what are the zombies in the anthropology of religion?

I can think of two concepts that I find it difficult to 'decide' - i.e. that I find it difficult to place in the binary schema of the anthropology of religion. They are 'me' and 'God'. (The zombie analogy might perhaps have been a bit hasty...) I have problems with the concept of 'me' because when pressed into the anthropology of religion schema it seems to become somewhat schizophrenic:

$$
\begin{aligned}
& \text { Me (private) : Me (academic) } \\
& \text { Me (constituted by the Other) : Me (studying the Other) } \\
& \text { Me: No questioning : Incessant questioning }
\end{aligned}
$$

I have the feeling Lacan would point out immediately that my neat binary division of me/me reflects the process of splitting myself. The classic defence mechanism that we use to be able to cope with - displace - dangerous material. 
The concept of 'God' is problematic for slightly different reasons. The anthropology of religion has already decided where to place it:

$\begin{array}{rll}\text { Private } & : & \text { Academic } \\ \text { Irrelevant to research } & : & \text { The researched reality } \\ \text { God } & : & -\end{array}$

However, the research subjects of the anthropology of religion have also decided where they place God:

$$
\begin{array}{rll}
\text { Irrelevant to research } & : & \text { The researched reality } \\
- & : & \text { God }
\end{array}
$$

The concept of God seems a bit slippery. No, let me rephrase that: the concept of the presence of God makes us slip. To bring in a slippery God would cross the sacred private/academic divide. I guess that to suggest that God may or may not be present in an anthropological text about religion constitutes about the same degree of heresy as suggesting that God may or may not be present in a Christian church service. The heretical uncertainty - especially uncertainty about God, especially within the anthropology of religion - must be confined to the private sphere and not impinge on the academic (on pain of losing the privilege to be called 'academic'). So perhaps what we have here is the ironic situation that the most effective way to destabilise the anthropology of religion is to bring in one of the most religious concepts of all, God. Bring in God - not in order to place the concept of God on one side or the other, but as a means to question the way the binary oppositions fit together and to introduce instead something that doesn't fit together. Simply because that seems in many ways to be a more plausible - not to say sincere - piece of research; God doesn't fit neatly together, life doesn't fit neatly together, sincere research doesn't stand a chance in hell of fitting neatly together.

So far, so good; I now have two destabilisers of the anthropology of religion: me and God. Perhaps the zombie analogy works at one level after all; me and God must rank pretty high among concepts that have freaked people out over the centuries.

\section{SATURDAY}

Early morning. Am still half asleep but have worked out the future of the anthropology of religion. It's like this: The interrupted dynamic between an understanding of the Self and of the Other in the anthropology of religion goes back to the Enlightenment division between reason and religion. The Enlightenment's grand-narrative-builders equated knowledge with reason, and reason with progress. Reason would triumph in the end if good men just put their mind to the task. Religion, on the other hand - effeminate and based on un-reason - stood in the way of such progress. I don't think this binary division in the realm of knowledge holds today. In the field of the anthropology of religion, at least, the binary opposition of reason versus religion is not the best way to understand the religion of the Other - or of the Self - any longer. So all I need to do is just break down the old binarism and re-arrange the nature of knowledge in the anthropology of religion. Great. Then I can write the PhD.

Now awake. Which is a pity because it means I am now far more confused than I was in my state of liminal clarity early this morning. Have spent a couple of hours going back and forth over Derrida's chapter on faith and knowledge, in the naïve hope the he must have put in one 
understandable key sentence somewhere. Am not quite sure but this quote on the supposed binary opposition of reason versus religion might be important:

\begin{abstract}
I also told myself, silently, that one would blind oneself to the phenomenon called 'of religion' or of the 'return of the religious' today if one continued to oppose so naïvely Reason and Religion, Critique or Science and Religion, technoscientific Modernity and Religion. Supposing that what was at stake was to understand, would one understand anything about 'what's-going-on-today-in-the-world-with-religion'...if one continues to believe in this opposition, even in this incompatibility, which is to say, if one remains within a certain tradition of the Enlightenment, one of the many Enlightenments of the past three centuries.... certain filiation 'Voltaire-Feuerbach-Marx-Nietzsche-Freud-(and even)-Heidegger'? (Derrida 2002:65, original emphasis)
\end{abstract}

I still don't quite understand. What he seems to be saying is that one of the traditions to emerge out of the Enlightenment was the academic assumption that critical reason, once developed far enough, would have to put an end to religion. And therefore, obviously, we locate our Self on the (winning) side of reason while confining the (losing) side of religion to the world of the Other. But, if what is at stake today is to understand religion, this academic tendency will not help us any longer; ' ... would one understand anything about "what's-going-on-today-in-the-world-withreligion" ... if one continues to believe in this opposition ...?'

Going back to Foucault's quote on the analysis of apparent oppositions - one might say:

$\ldots$ at base anthropology is not really endorsing or denying the binary opposition reason/religion (though it does not exclude it); but anthropology introduces to reason/religion, it develops, starting with reason/religion, an entire complex mechanism in which it is a question of the constitution of division, of divided subjectivity... of the Other on the one hand and the Self on the other.

So, following Foucault, the double phenomenon of reason and religion, which is assumed to be contradictory, might be more understandable today if we instead explore the means by which the two sides of the phenomenon co-exist. And perhaps even sustain each other.

\title{
SUNDAY
}

Have had a disjointed day. It started when I jerked awake this morning after a frightening dream that involved a massive throne of judgement, a half-lit library, and somebody posing under the false identity of Nietzsche, who tried to grab hold of my hands with the words 'Careful, you might lose something - your fingertips!'; his motive (though this was a bit unclear) being that if he cut off my fingertips I would no longer be able to write. I was relieved to discover when I woke up that at least my hands were still intact, though the same could not be said for my feeling of mental equilibrium.

Then there was the church service. I went to a church I had seen down the road, notebook in hand. By chance, I hit on a service where the sermon was taken from Ezekiel where God is described in full glory. The vicar elaborated on the theme of the magnificent God, the triumphal God, the omniscient God, etc. Sitting there in the pew I felt particularly stuck between the vicar's triumphantly present God and the anthropologists' decidedly absent God. Looking at the people sitting around me, I wondered what different mixtures of presence and absence God meant for them.

When I came back home after the service I wrote up some notes. I tried to apply some of the thoughts from this past week to the way I was writing - I tried to avoid placing God as either there or not there, and instead to use the possibility/undecidability of God as a means of 
understanding the people in the service, and, subsequently, to link this understanding back to an understanding of the influence it had on me, and what clues this might provide to the religious event I was trying to describe and interpret.

My attempt failed miserably. Whenever I tried to bring God into the anthropological text as an undecidable possibility rather than a decided absence, I was not able to find the words to write. And whenever I tried to cross the line back to myself - not just my presence in the service, but my beliefs and the way they were influenced by the service - it felt like I was committing sacrilege within the academic system. In the end I wrote up a standard account of the service, making it as anthropological as I could, with any beliefs of my own bracketed out and with my hopefully empathic interpretations informed by a Geertzian thick description of 'what they think they're doing'. The account doesn't tell me anything new, which is probably not a good sign (careful, I might have lost something, to use an apt phrase -) but at least it'll pass as an 'academic' piece of work. I guess tomorrow I'll start reading the list of ethnographies that I'm supposed to be reading.

\section{BIBLIOGRAPHY:}

Deleuze, Gilles \& Félix Guattari. 1987. A Thousand Plateaus; Capitalism \& Schizophrenia, translated by Brian Massumi. London: Continuum.

Derrida, Jacques. 1997. Of Grammatology, translated by Gayatri Chakravorty Spivak. Baltimore: Johns Hopkins University Press.

Derrida, Jacques. 2002. "Faith and Knowledge: The Two Sources of "Religion" at the Limits of Reason Alone'. In Acts of Religion, edited by Gil Anidjar. London: Routledge, pp. 42-101.

Foucault, Michel. 1978. 'Politics and the Study of Discourse'. Ideology and Consciousness, 3:726.

Foucault, Michel. 1999. 'Sexuality and power'. In Religion and Culture by Michel Foucault, selected and edited by Jeremy Carrette. Manchester: Manchester University Press, pp. 115-130.

Lacan, Jacques. 1977. Écrits; A Selection. London: Routledge.

\section{ABOUT THE CONTRIBUTOR:}

Ingie Hovland is a PhD student in the Department of Anthropology, at the School of Oriental and African Studies (SOAS), London. Her PhD research is on the Norwegian Mission Society, focusing on how missionaries and others in the mission society think about themselves and how this has changed from the 1840 s till today.

\section{Anthropology Matters J ournal, 2003-2}

